\title{
47. PETROLEUM-GENERATING POTENTIAL OF SEDIMENTS FROM LEG 48, DEEP SEA DRILLING PROJECT
}

\author{
J.W. Kendrick, A. Hood, and J.R. Castaño, Shell Development Company, Houston, Texas
}

\begin{abstract}
Chemical and petrographic analyses of organic matter indicate that the petroleum-generating potential of sediments recovered by the Deep Sea Drilling Project from the Bay of Biscay and the Rockall Plateau is poor. At present, these sediments have not been buried deeply enough to reach the temperatures necessary for significant petroleum generation. More importantly, the sediments contain small amounts of organic matter, which is primarily hydrogen-deficient, land-plant material. Consequently, only small amounts of petroleum would be generated during continued burial and subsurface heating.
\end{abstract}

\section{INTRODUCTION}

Leg 48 of the Deep Sea Drilling Project (DSDP) was devoted to drilling in the Bay of Biscay and on the Rockall Plateau. We obtained several samples from Leg 48 for the purpose of assessing the petroleum-generating potential of sediments from these two regions.

The sediments which we analyzed come from a collection of cores which were frozen and set aside for organic geochemical studies. Using preliminary analyses by DSDP, we selected samples from those cores which appeared to contain above average amounts of organic carbon. The majority of samples are Lower Cretaceous sediments from Hole $402 \mathrm{~A}\left(47^{\circ} 52.5^{\prime} \mathrm{N}, 8^{\circ} 50.4^{\prime} \mathrm{W}\right)$ in the Bay of Biscay. The remaining samples are Eocene sediments from Site 403 $\left(56^{\circ} 08.3^{\prime} \mathrm{N}, 23^{\circ} 17.6^{\prime} \mathrm{W}\right)$ and Site $404\left(56^{\circ} 3.1^{\prime} \mathrm{N}\right.$, $23^{\circ} 15.0^{\prime} \mathrm{W}$ ) on the Rockall Plateau.

In assessing the petroleum-generating potential of these samples, we determine whether the sediments contain enough thermally reactive organic matter for significant petroleum generation and whether the sediments have experienced subsurface temperatures sufficiently high for the thermal conversion of kerogen to petroleum. Our analytical methods have been described previously (Hood et al., 1976). Briefly summarized, we use organic carbon (Corg), effective carbon ( $\mathrm{C}_{\text {eff }}$, and pyrolysis fluorescence. $(\mathrm{PF})$ to estimate the amounts of both total and thermally reactive organic matter in the sediments. To determine the thermal maturity of the organic matter, we measure the reflectance (in oil) of vitrinite. In addition, we estimate the relative abundance of the macerals which constitute the kerogen.

\section{RESULTS}

\section{Content of Organic Matter}

We consider 1.0 to 1.5 per cent organic carbon to be the minimum amount necessary for a sediment to be considered a potential, or future, source rock of petroleum. This criterion is based on work by Schrayer and Zarella (1963) and Ronov (1958), who determined the average organic carbon contents of sediments in both petroliferous and non- petroliferous sedimentary basins. We regard laboratory pyrolysis techniques as better indicators of petroleumgenerating potential, however, because they measure directly the amount of petroleum-like material generated by heating. Effective carbon (the pyrolyzable carbon measured by a flame ionization detector) and pyrolysis fluorescence are two such measures of thermally reactive organic matter (Hood et al., 1976). It is our opinion that a sediment must have an effective carbon content of 0.26 per cent $(0.3 \%$ hydrocarbon) or a pyrolysis fluorescence value of 10 units before it can possibly be considered a potential petroleum source rock.

The sediments analyzed from Leg 48 have organic carbon contents ranging from 0.23 to 2.00 per cent (Table 1). The larger values are high enough to suggest that those sediments are potential source rocks. The effective carbon contents of these same samples, however, are all less than 0.06 per cent, and pyrolysis fluorescence (PF) gives no signal at

TABLE 1

Amount of Organic Matter

\begin{tabular}{|c|c|c|c|c|c|c|}
\hline $\begin{array}{c}\text { Sample } \\
\text { (Interval in } \mathrm{cm} \text { ) }\end{array}$ & $\begin{array}{l}\text { Depth } \\
\text { (m) }\end{array}$ & Age & $\% \mathrm{C}_{\text {org }}$ & $\mathrm{PF}^{\mathrm{a}}$ & $\% \mathrm{C}_{\mathrm{eff}}$ & $\frac{C_{\text {eff }}}{C_{\text {org }}}$ \\
\hline \multicolumn{7}{|l|}{ Hole $402 \mathrm{~A}$} \\
\hline $\begin{array}{l}13-3,0-5 \\
15-1,14-16 \\
18-1,9-13 \\
21-1,51-53 \\
24-1,42-45 \\
30-1,32-37 \\
33-1,62-65 \\
35-4,53-57\end{array}$ & $\begin{array}{l}254 \\
270 \\
299 \\
328 \\
356 \\
413 \\
442 \\
465\end{array}$ & $\begin{array}{l}\text { Albian } \\
\text { Albian? } \\
\text { Albian? } \\
\text { Albian? } \\
\text { Albian } \\
\text { Aptian } \\
\text { Aptian } \\
\text { Aptian }\end{array}$ & $\begin{array}{l}0.66 \\
1.19 \\
1.62 \\
1.86 \\
1.38 \\
2.00 \\
1.10 \\
0.35\end{array}$ & $\begin{array}{l}0 \\
0 \\
0 \\
0 \\
0 \\
0 \\
0 \\
0\end{array}$ & $\begin{array}{l}0.02 \\
0.02 \\
0.03 \\
0.04 \\
0.01 \\
0.06 \\
0.01 \\
0.01\end{array}$ & $\begin{array}{l}0.03 \\
0.02 \\
0.02 \\
0.02 \\
0.01 \\
0.03 \\
0.01 \\
0.03\end{array}$ \\
\hline \multicolumn{7}{|l|}{ Site 403} \\
\hline \multicolumn{7}{|l|}{ Site 404} \\
\hline $\begin{array}{l}17-4,54-58 \\
22-6,50-55\end{array}$ & $\begin{array}{l}299 \\
350\end{array}$ & $\begin{array}{l}\text { Eocene } \\
\text { Eocene }\end{array}$ & $\begin{array}{l}0.38 \\
0.38\end{array}$ & $\begin{array}{l}0 \\
0\end{array}$ & $\begin{array}{l}<0.01 \\
<0.01\end{array}$ & $\begin{array}{l}- \\
-\end{array}$ \\
\hline
\end{tabular}

${ }^{\text {a Arbitrary units. }}$ 
all (Table 1). Both pyrolysis techniques therefore indicate that only a small fraction (less than $3 \%$ ) of the organic carbon in any one sample is thermally convertible to hydrocarbons. Consequently, none of the samples appears to be capable of generating a sufficient amount of hydrocarbons to be considered a potential source rock of petroleum.

\section{Thermal Maturity}

The quality of the vitrinite in the Leg 48 samples is poor. The vitrinite particles frequently exhibit cracks and pits indicative of oxidation and reworking. The presence of vitrinite recycled from sediments with a prior thermal history or of oxidized vitrinite will often be manifested by vitrinite reflectance values which are higher than those of unoxidized, primary vitrinite (Hood and Castaño, 1974). Such values, however, are not indicative of the sediment's true level of thermal maturity.

The influence of reworked vitrinite is apparent in the histograms of vitrinite reflectance for Hole $402 \mathrm{~A}$, plotted as a function of depth on Figure 1. The deepest sample, at 465 meters, exhibits a mode between 0.2 and 0.5 per cent Ro which represents primary vitrinite with a mean reflectance of 0.32 per cent. The sediments at 299 and 413 meters display modes which are similar to, though not as well developed as, the mode of primary vitrinite at 465 meters. All of the samples, however, have reflectance values greater than $0.5 \%$. These higher values imply that a major portion of the vitrinite is reworked and therefore is not an accurate indication the sediment's thermal maturity. In Table 2 we have specifically denoted the populations of primary vitrinite reflectance values with the letter " $A$ ", to distinguish them from the populations of all reflectance measurements (denoted with an " $\mathrm{X}$ "). Although some amount of primary vitrinite appears to be present in each of the samples, we have given " $A$ " values only for those samples in which the primary and reworked vitrinite populations are readily distinguishable.

The sediments analyzed from the Rockall Plateau also include large components of reworked vitrinite, but the one sample from Site 403 clearly contains primary vitrinite with a mean reflectance of 0.31 per cent (Table 2). A second sample, from Site 404, contains somewhat less primary vitrinite with a mean reflectance of 0.34 per cent.

Significant oil generation begins at maturity levels corresponding to about $0.5 \% \mathrm{R}_{\mathrm{o}}$ (Hood and Castaño, 1974; Hood et al., 1975). Therefore the vitrinite reflectance determinations for Leg 48 indicate that the sediments encountered in the Bay of Biscay and on the Rockall Plateau are still thermally immature.

\section{Types of Organic Matter}

During the measurements of vitrinite reflectance, the composition of the organic matter was estimated visually, using the classification system indicated in Table 3 . Hydrogen-rich organic matter is classified as liptinite or amorphous kerogen, depending on whether it is structured (spores, algae, etc.) or unstructured. Vitrinite is hydrogenpoor organic matter, typically derived from woody land plants. Inertinite includes thermally inert macerals such as fusinite, semi-fusinite, and micrinite.

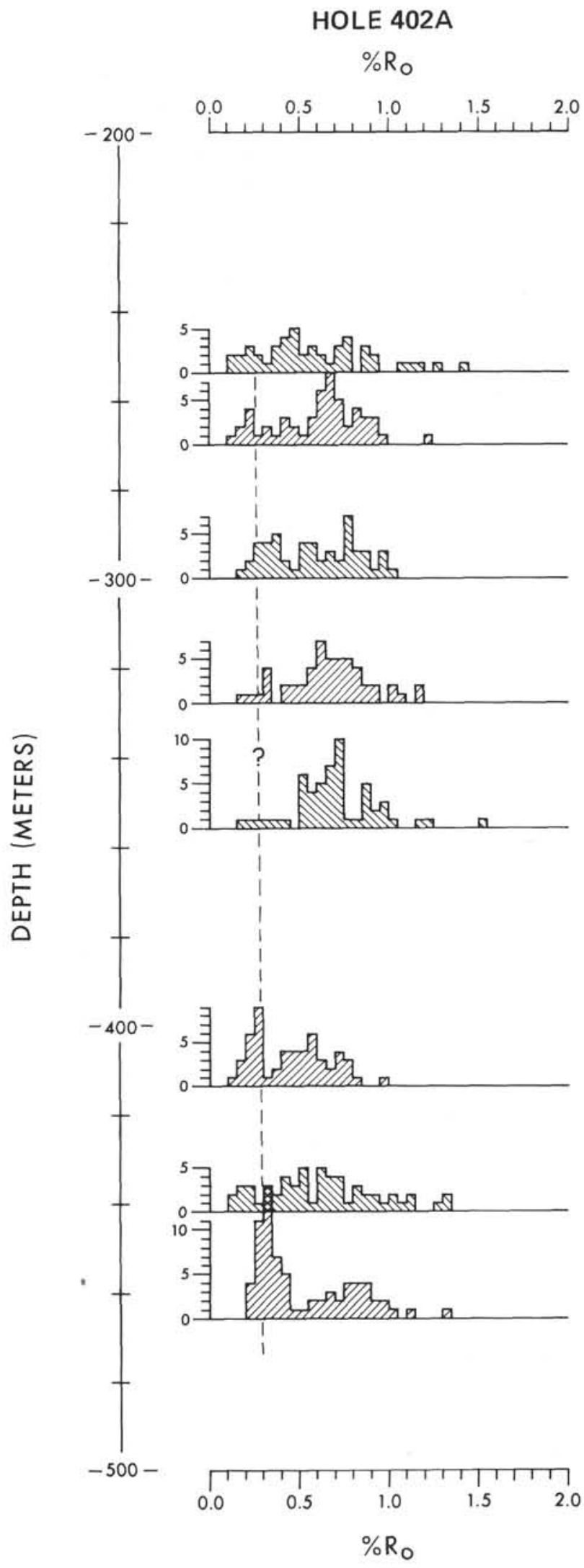

Figure 1. Histograms of vitrinite reflectance (Ro) plotted as a function of depth (in m.) for Site 402. The dashed line represents the inferred trace of Ro for primary vitrinite. 
TABLE 2

Vitrinite Reflectance

\begin{tabular}{|c|c|c|c|c|c|}
\hline $\begin{array}{c}\text { Sample } \\
\text { (Interval in cm) }\end{array}$ & $\begin{array}{l}\text { Depth } \\
\text { (m) }\end{array}$ & $\underset{\text { Population }^{\mathrm{a}}}{\mathrm{R}_{\mathrm{o}}}$ & $\begin{array}{c}\text { No. of } \\
\text { Observations }\end{array}$ & $\begin{array}{l}\text { Range } \\
\left(\% R_{0}\right)\end{array}$ & 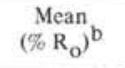 \\
\hline \multicolumn{6}{|l|}{ Hole $402 \mathrm{~A}$} \\
\hline $13-3,0-5 \mathrm{~cm}$ & 254 & $\mathrm{x}$ & 52 & $0.14-1.43$ & $0.59 \pm 0.09$ \\
\hline $15-1,14-16$ & 270 & $\mathrm{x}$ & 52 & $0.14-1.24$ & $0.61 \pm 0.07$ \\
\hline \multirow[t]{2}{*}{$18-1,9-13$} & 299 & $\mathrm{~A}$ & 19 & $0.16-0.48$ & $0.32=0.04$ \\
\hline & & $\mathrm{X}$ & 52 & $0.16-1.01$ & $0.58 \pm 0.07$ \\
\hline $21-1,51-53$ & 328 & $\mathrm{X}$ & 52 & $0.16-1.17$ & $0.67 \pm 0.07$ \\
\hline $24-1,42-45$ & 356 & $\mathrm{X}$ & 54 & $0.18-1.50$ & $0.70 \pm 0.07$ \\
\hline \multirow[t]{2}{*}{$30-1,32-37$} & 413 & A & 20 & $0.14-0.30$ & $0.23 \pm 0.02$ \\
\hline & & $\mathrm{X}$ & 54 & $0.14-0.95$ & $0.45 \pm 0.06$ \\
\hline $33-1,62-65$ & 442 & $\mathrm{x}$ & 54 & $0.13-1.35$ & $0.64 \pm 0.09$ \\
\hline \multirow[t]{2}{*}{$34-4,53-57$} & 465 & A & 43 & $0.23-0.46$ & $0.32 \pm 0.02$ \\
\hline & & $\mathrm{X}$ & 72 & $0.23-1.34$ & $0.51 \pm 0.06$ \\
\hline \multicolumn{6}{|l|}{ Site 403} \\
\hline \multirow[t]{2}{*}{$37-6,30-34$} & 345 & A & 47 & $0.19-0.42$ & $0.31 \pm 0.02$ \\
\hline & & $x$ & 72 & $0.19 \cdot 1.16$ & $0.48 \pm 0.06$ \\
\hline \multicolumn{6}{|l|}{ Site 404} \\
\hline \multirow[t]{2}{*}{$17-4,54-58$} & 299 & A & 13 & $0.24-0.44$ & $0.34 \pm 0.04$ \\
\hline & & $\mathrm{x}$ & 28 & $0.24-1.13$ & $0.60 \pm 0.11$ \\
\hline $22-6,50-55$ & 350 & $\mathrm{X}$ & 8 & $0.57-1.07$ & $0.87 \pm 0.14$ \\
\hline
\end{tabular}

a" $\mathrm{X}$ " represents the population of all vitrinite reflectance measurements; " $\mathrm{A}$ " represents the population of reflectance measurements interpreted to be primary

vitrinite.
$\mathrm{b}_{\%} \mathrm{R}_{\mathrm{o}} \pm 95 \%$ confidence limits.

TABLE 3

Maceral Composition of Kerogen ${ }^{\text {a }}$

\begin{tabular}{ccccc}
\hline $\begin{array}{c}\text { Sample } \\
\text { Interval in cm) }\end{array}$ & $\begin{array}{c}\text { Amorphous } \\
\text { Kerogen }\end{array}$ & Liptinite & Vitrinite & Inertinite \\
\hline
\end{tabular}

Hole 402A

$13-3,0-5$

$15-1,14-16$

$18-1,9-13$

21-1, $51-53$

$24-1,42-45$

$30-1,32-37$

$33-1,62-65$

$35-4,53-57$

$\begin{array}{ll}1 & 1 \\ 4 & 1 \\ 1 & 1 \\ 4 & 1 \\ 1 & 1 \\ 1 & 1 \\ 1 & 2 \\ 1 & 1\end{array}$

1
1
1
1
1
1
2
1

$\begin{array}{ll}7 & 1 \\ 6 & 3 \\ 7 & 3 \\ 6 & 3 \\ 7 & 3 \\ 7 & 1 \\ 6 & 5 \\ 7 & 3\end{array}$

Site 403

$37-6,30-34$

1

1

7

2

Site 404

$17-4,54-58$

$22-6,50-55$

1
1

1

7
7

2

${ }^{a}$ Numerical abundance scale and percentage (By Area): $1=0-1 \%$; $2=2-5 \% ; 3=6-10 \% ; 4=11-15 \% ; 5=26-50 \% ; 6=51-75 \% ; 7=76-$ $100 \%$.

The visual kerogen analyses (Table 3 ) indicate that the kerogen in the sediments from Leg 48 is composed primarily of vitrinite, with secondary amounts of inertinite. The vitrinitic character of the kerogen indicates that the organic matter is terrigenous in nature. Amorphous kerogen, which was recognized in two samples from the Bay of Biscay, may reflect an input of aquatic organic matter, but such material appears to be a minor component of the total organic matter. The amounts of amorphous kerogen are not sufficiently great to affect the ratio of $\mathrm{C}_{\text {eff }}$ to $\mathrm{C}_{\text {org }}$ (Table 1), which is an index of the kerogen's hydrogen content (Kendrick, 1979).

\section{DISCUSSION}

The preceding analyses indicate that the petroleumgenerating potential of the Leg 48 sediments is poor. The kerogen constitutes a small fraction of these sediments and is composed primarily of hydrogen-poor, terrigenous organic matter. As a result, only small amounts of organic matter are thermally convertible to petroleum. Furthermore, the sediments have not been buried deeply enough to reach the temperatures at which significant petroleum generation occurs.

The poor source rock potential of Eocene sediments on the Rockall Plateau is not anomalous because large concentrations of organic matter have not previously been reported for Eocene sediments in the Atlantic Ocean. The limited quantities of organic matter in the Lower Cretaceous sediments at Site 402, however, are significant because Cretaceous sediments rich in organic matter have been encountered at numerous core holes in the North Atlantic Ocean (Lancelot, et al., 1972; Berger and von Rad, 1972; Lancelot, Seibold, et al., 1977).

Whereas the Cretaceous so-called black clays appear to be widely distributed, their petroleum-generating potential is highly variable, ranging from poor to good (Kendrick et al., 1978, 1979). This variability may result from differences in the depositional setting at various locations. Kendrick (1979) indicates that differences in the amount and composition of organic matter in Cretaceous black clays may be related to the existence or absence of anaerobic conditions during deposition. In particular, hydrogen-deficient, terrigenous organic matter appears to be more resistant to oxidative destruction than amorphous, marine-derived kerogen. The maceral composition and effective carbon contents of the Cretaceous sediments of Site 402 imply that the sediments were not deposited under highly reducing conditions.

A second core hole in the Bay of Biscay, Site 400, also contains carbonaceous, Cretaceous sediments. The Lower Cretaceous sediments at Site 402 differ from those at Site 400 because they were deposited in shallow (inner shelf) water depths, whereas sedimentation at Site 400 occurred in bathyal water depths (see respective site summary chapters). A comparison of the amount and types of organic matter at both sites could be important in determining whether the Bay of Biscay was a stratified water body in which the deeper waters were highly reducing or whether the deep waters were well aerated too. Unfortunately, no organic geochemistry samples were available from Site 400 .

\section{ACKNOWLEDGMENTS}

The authors wish to thank P.R. Mommessin, J.M. Hunt, and D.B. Pearson for reviewing the manuscript.

\section{REFERENCES}

Berger, W.H. and von Rad, U., 1972. Cretaceous and Cenozoic sediments from the Atlantic Ocean. In Hayes, D.E., Pimm, A.C., et al., Initial Reports of the Deep Sea Drilling Project, v. 14: Washington(U.S. Government Printing Office), p. 787-954.

Hood, A. and Castaño, J.R., 1974. Organic metamorphism: Its relationship to petroleum generation and application to studies of authigenic minerals, United Nations ESCAP, CCOP Tech. Bull., v. 8, p. $85-118$. 
Hood, A., Gutjahr, C.C.M., and Heacock, R.L., 1975. Organic metamorphism and the generation of petroleum, Am.Assoc. Petrol. Geol. Bull., v. 59, p. 986-997.

Hood, A., Castaño, J.R., and Kendrick, J.W., 1976. Petroleumgenerating potential and thermal history of DSDP Leg 38 sediments. In Talwani, M., Udintsev, G., et al., Initial Reports of the Deep Sea Drilling Project, v. 38: Washington (U.S. Government Printing Office), p. 801-804.

Kendrick, J.W., 1979. Geochemical studies of black clays from Leg 43, Deep Sea Drilling Project. In Tucholke, B., Vogt, P., et al., Initial Reports of the Deep Sea Drilling Project, v. 43: Washington (U.S. Government Printing Office), p. 633-642.

Kendrick, J.W., Hood, A., and Castaño, J.R., 1979. Petroleumgenerating potential of Cretaceous sediments from Leg 43, Deep Sea Drilling Project. In Tucholke, B., Vogt, P. et al., Initial Reports of the Deep Sea Drilling Project, v. 43: Washington(U.S. Government Printing Office), p. 663-668. , 1978. Petroleum-generating potential of sediments from Leg 44, Deep Sea Drilling Project. In Benson, W.E.,
Sheridan, R.E., et al., Initial Reports of the Deep Sea Drilling Project, v. 44: Washington (U.S. Government Printing Office), p. 599-604.

Lancelot, Y., Hathaway, J.C., and Hollister,C.D., 1972. Lithology of sediments from the western North Atlantic, Leg XI, Deep Sea Drilling Project. In Ewing, J.I., Hollister, C.D., et al., Initial Reports of the Deep Sea Drilling Project, v. 11: Washington (U.S. Government Printing Office), p. 901-949.

Lancelot, Y., Seibold, E., et al., 1978. Initial Reports of the Deep Sea Drilling Project, v. 41: Washington (U.S. Government Printing Office).

Ronov, A.B., 1958. Organic carbon in sedimentary rocks (in relation to the prescence of petroleum), Geochemistry (a translatio of Geokhimiya), no. 5, p. 510-536.

Schrayer, G.J. and Zarella, W.M., 1963. Organic geochemistry of shales - I. Distribution of organic matter in siliceous Mowry Shale of Wyoming, Geochim. Cosmochim. Acta, v. 27, p. 1033-1046. 